\title{
REKAYASA PROSES BISNIS PADA E-COMMERCE B2B-B2C MENGGUNAKAN SISTEM AFILIASI
}

\author{
Febri Nova Lenti \\ Teknik Informatika STMIK AKAKOM \\ J1. Raya Janti Karang Jambe No. 143 Yogyakarta 55198, Indonesia \\ e-mail: febri@akakom.ac.id
}

\begin{abstract}
ABSTRAK
E-Commerce B2B-B2C adalah jenis E-Commerce dengan bentuk interaksi Bussiness to Bussiness (B2B) dan Bussiness to Customer(B2C) dimana terjadi interaksi antara produsen (perusahaan, industri rumah tangga, penyedia barang dan jasa) dengan distributor dan pengecer, yang kemudian dilanjutkan oleh distributor dan pengecer ke konsumen berbasiskan media elektronik yang terhubung ke jaringan internet. Sistem ini di rekayasa dengan menggunakan model proses bisnis Sistem Afiliasi dimana aktifitas dalam sistem ini menjualkan produk atau jasa milik orang lain tanpa harus membeli atau memiliki produk atau jasa tersebut. Sistem afiliasi ini menggunakan sistem bagi hasil atau komisi sesuai dengan kesepakatan. Pada Penelitian ini telah diteliti dukungan sistem afiliasi terhadap interaksi B2B-B2C serta penerapan teknologi informasi dan komunikasi yang tepat untuk mendukung proses bisnisnya. Hasil yang akan didapatkan dari penelitian ini adalah suatu sistem E-Commerce yang menyediakan layanan untuk mendukung kemudahan proses transaksi jual beli secara online dan mobile dari penyedia barang dan jasa ke pengecer maupun dari pengecer ke konsumen.
\end{abstract}

Kata Kunci: E-Commerce, Proses Bisnis, B2B, B2C, Afiliasi, penyedia barang, pengecer, konsumen

\begin{abstract}
E-commerce B2B-B2C is a kind of E-commerce with forms of interaction Bussiness to Bussiness (B2B) and Bussiness to Customer (B2C) where there is interaction between producers (company, home industries, providers of goods and services) with distributors and retailers, which followed by distributors and retailers to consumers based on electronic media that is connected to the internet. The system is engineered using Affiliate System where the activity in these systems sell products or services of another person without having to buy or have products or services. The affiliate system uses a system of revenue sharing or commission in accordance with the agreement. How affiliate system can support B2B-B2C interactions as well as the application of information and communication technology appropriate to support business processes will be explorated in this research. Results to be obtained from this research is an E-commerce system that provides ease of process to support an information system of selling based on mobile and web from providers of goods and services to retailer and from the retailer to the consumer.
\end{abstract}

Keywords:E-Commerce, Business Process, B2B, B2C, Afiliate, provider of goods, retailers, consumers

\section{Pendahuluan}

$\mathrm{P}$ erdagangan elektronik atau yang lebih dikenal dengan e-commerce di Indonesia kini sedang hangathangatnya. Banyak pelaku di bidang ini yang bermunculan untuk memanfaatkan potensi jumlah penduduk Indonesia yang banyak. Selain itu, tingkat kesadaran konsumen terhadap e-commerce juga terus meningkat dengan mulai mengadopsi kebiasaan berbelanja online. Agustin menyatakan [8] bahwa BMI Research mencatat bahwa rata-rata pengeluaran belanja online orang Indonesia dalam setahun mencapai Rp 825.000 per orang. Tahun lalu saja, nilai transaksi belanja online orang Indonesia mencapai Rp 21 triliun. Angka ini diproyeksi akan meningkat signifikan di tahun 2015, yakni hingga mencapai Rp 50 triliun atau meningkat lebih dari dua kali lipat.

Aplikasi penjualan berbasis internet dan android merupakan aplikasi aplikasi tentang pengolahan data informasi dan banyak digunakan dalam e-commerce. Aplikasi Android adalah aplikasi pada device Smartphone, Tablet dan device lain yang menggunakan sistem operasi Android yang dibuat menggunakan bahasa pemrograman Java. Aplikasi ini tidak membutuhkan web browser untuk mengaksesnya seperti pada aplikasi berbasis internet. Akan tetapi, aplikasi-aplikasi penjualan berbasis internet dan android yang beredar pada saat ini uumnya hanya berorientasi untuk transaksi antara penjual dan pembeli (konsumen) baik secara grosir maupun eceran, sehingga pemilik atau penjual harus berusaha sendiri mempromosikan barang dagangannya. Selain itu, pemilik ataupun penjual itu sendiri harus banyak menyediakan stok barang dagangannya.

Pratama [4] E-Commerce B2B-B2C adalah jenis E-Commerce dengan bentuk interaksi Bussiness to Bussiness (B2B) dan Bussiness to Customer (B2C) dimana terjadi interaksi antara produsen ( perusahaan, industri rumah tangga, penyedia barang dan jasa) dengan distributor dan pengecer, yang kemudian dilanjutkan oleh distributor dan pengecer ke konsumen berbasiskan media elektronik yang terhubung ke jaringan internet. Dengan begitu terdapat Manufacturing Supply Chain yang terdiri dari Manufacturer (M), Supplier (S) dan Customer (C) pada ECommerce sehingga tidak sekedar antara penjual dan pembeli. 
Das saumendra [4] dalam buku E-Commerce, E-Business dan Mobile Commerce Berbasiskan Open Source mengatakan untuk merekayasa proses bisnis E-Commerce B2B-B2C digunakan sistem bisnis afiliasi yang berperan urntuk memadukan Manufacturing Supply Chain. Afiliasi adalah aktifitas dalam menjualkan produk atau jasa milik orang lain tanpa harus membeli atau memiliki produk atau jasa tersebut. Sistem afiliasi ini menggunakan sistem bagi hasil atau komisi sesuai dengan kesepakatan

Oleh karena itu penelitian ini akan meneliti dan mengeksplorasi rancang bangun sistem affiliasi penjualan pada E-Commerce agar dapat meningkatkan penjualan produk serta mempermudah komunikasi dengan para affiliator.

Beberapa penelitian yang berhubungan dengan E-Commerce yang pernah dilakukan diantaranya adalah Sufendi dkk [6] dengan studi kasus penjualan dan pemesanan batik, wong dkk [9] dengan studi kasus penjualan HP, pada penelitian Sufendi, dkk [6] jenis E-Commerce yang dikembangkan adalah B2C, dan pada penelitian Wong, dkk [9] jenis E-Commerce yang dikembangkan adalah B2B-B2C-C2C

Beberapa penelitian yang pernah dilakukan terkait dengan Bisnis afiliasi diantaranya adalah yang dilakukanoleh Safitri dan Sujito [5] dengan kasus Paramita Member Club, Jannatun [1] dengan kasus toko mebel. Kedua penelitian tadi dimodelkan proses bisnis mirip multilevel marketing dimana affiliator dapat mencari teman lainnya dan mendapatkan komisi berlevel. Pada penelitian ini model proses bisnis yang digunakan bukan multi level marketing.

\section{A. Mengenal E-Commerce}

E-Commerce menurut Chuffey [4] adalah semua bentuk proses pertukaran informasi antara organisasi dan stakeholder berbasiskan media elektronik yang terhubung ke jaringan internet. Pratama [4] menyatakan empat komponen penting didalam E-Commerce, yaitu : Penjual, Konsumen, Tehnologi dan Jaringan Komputer.

Cara kerja E-Commerce sama dengan pasar di dunia fisik dan proses transaksi di dunia nyata (fisik). Yang membedakannya adalah kegiatannya dilakukan secara online dan digital (tanpa melibatkan tatap muka langsung antara penjual dan pembeli) serta sedikit perbedaan pada proses bisnis didalamnya.Sebuah e-commerce memiliki setidaknya beberapa buah poin penting di dalammnya, terkait dengan proses kerjanya tersbut, yaitu :

1) Terdapat produk (barang maupun jasa) yang diperjual belikan

2) Terdapat konsumen online yang berminat dengan produk yang ditawarkandan transaksi yang terjadi kemudian.

3) Terdapat mekanisme di dalam melayani konsumen, ke dalam sebuah tatap muka aplikasi (umumnya berbasis web). Dimulai dari sistem yang menangani proses katalog dan etalase online, sistem yang menangani produk mana saja yang diambil oleh konsumen secara online, sistem yang menangani pembayaran (semacam kasir) hingga sistem inventori (stok produk).

4) Terdapat proses pengiriman barang berdasarkan alamat yang diberikan konsumen yang telah melakukan pembayaran

5) Penanganan masalah logistik (stok barang) pada toko online atau inventori, untuk ketersediaan produk di dalam memenuhi permintaan konsumen. Termasuk juga dalam hal ini hubungannya dengan distributor atau supplier.

E-Commerce Business to Business (B2B) adalah bentuk interaksi e-commerce secara online yang terjadi antara prodiusen (perusahan, industri, penyedia barang dan jasa) dengan distributor (Supplier) dan pengecer. Distributor atau pengecer ini kemudian menyalurkan produk tersebut ke konsumen masing masing.

Didalam proses B2B terjadi kegiatan yang mencakup Supply Chain, pertukaran informasi, manajemen operasional dan lain lain. Ada tiga tahap pada e-commerce B2B, yaitu : Physical Distribution, Information Exchange, dan Business Process Integration. Pada tahap Physical Distribution terjadi distribusi produk secara fisik, dimana didalamnya melibatkan Manufacturing Supply Chain . Manufacturing Supply Chain terdiri atas Suplier (S), Manufacturer (M) dan Customer(C). Manufacturing Supply Chain terdiri atas dua bagian yaitu:

1) Upstream (level atas) yang melibatkan Supplier (S) dengan manufacturer (M). Manufacturer menyalurkan produk ke supplier, bukan ke konsumen akhir.

2) Downstream (Level bawah) yang melibatkan Manufacturer (M) dengan Customer (C). Manufacturer menyalurkan produk langsung ke konsumen akhir.

Pada tahap Information Excahange terjadi proses pertukaran informasi dimana B2B terjadi di sini anatara Supplier (S) dengan manufacturer (M) dan Manufacturer (M) dengan Customer (C). Tahap terakhir adalah Business Process Integration, dimana terjadi penggabuangan atau integrasi dari beberapa proses bisnis yang melibatkan kolaborasi antara Supplier dan Manufacturer serta kolaborasi Manufacturer dengan Customer.

E-commerce retail atau B2C merupakan bagian dari e-commerce yang menekankan kepada proses pemesanan, pembelian dan penjualan produk atau jasa melalui akses internet. Hal ini berarti bahwa penjual dan pembeli dapat langsung bertransaksi secara elektornik dan online, memanfaatkan fitur fitur yang disediakan.

E-commerce Retail B2C yang dilakukan secara online melibatkan pelaku-pelaku berupa Customer, Business Organization, dan Website. Pada Business Organization ke Customer, terdapat supplies yang berfungsi sebagai proses penyaluran atau distribusi (Supply)produk yang akan dijual. Kemudian antara Business Organization dan Website terjadi proses transaksi jual beli berupa pemrosesan pemesanan online (Order Processing). Dari Customer 
ke Website terdapat order, yang menyatakan kondisi dimana konsumen dapat melakukan pemesanan produk yang diinginkan (Order) secara online. Bagan dari B2C disajikan pada gambar 1.

Pratama [4] menyatakan E-commerce dengan model bisnis pemasaran afiliasi merupakan e-commerce yang didalamnya menyediakan konsep "bantu jual produk saya dan dapatkan komisinya". Terdapat beberapa keberagaman implementasi model bisnis ini, disebabkan karena banyaknya ide, proses bisnis, dan implementasi tehnologi yang dapat diterapkan kedalamnya, antara lain:

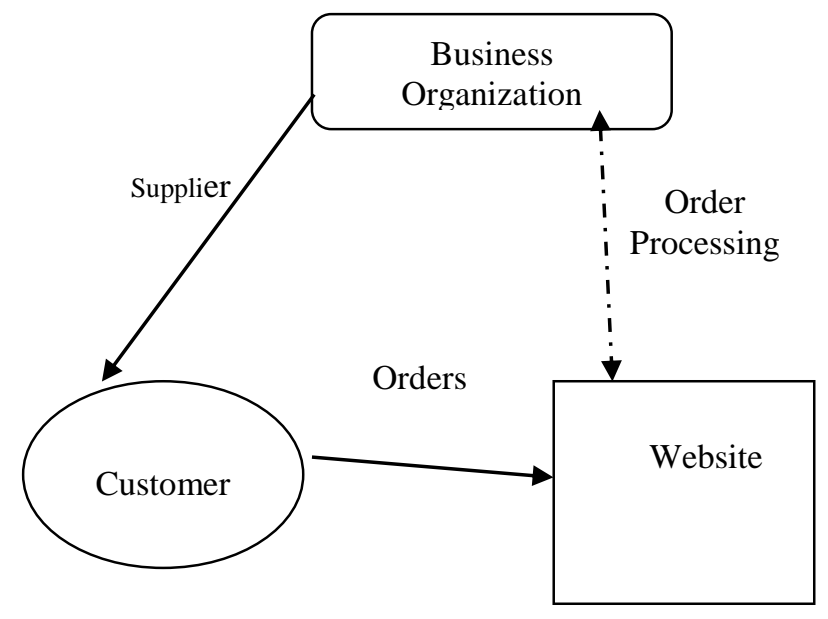

Gambar 1. Bagan E-Commerce B2C

1) Tersedia sebuah website yang menjual produk sendiri. Kemudian setiap pengunjung internet dapat registrasi ke dalam sistem pada website tersebut, lalu membeli produk dan memperoleh komisi langsung untuk setiap pembelian produk sesuai dengan perjanjian (misalkan sovenir maupun gratis ongkos kirim jika membeli lima produk sekaligus)

2) Seperti no 1 diatas, namun produk yang dijual adalah produksi perusahaan lain. Perusahaan menjadi penyedia barang, sementara pemilik web ikut membantu memasarkan secara online ( dan memperoleh komisi sesuai perjanjian). Pada beberapa kasus pemilik web dapat bekerja sama dengan banyak perusahaan sekaligus, sehingga tidak terpaku pada satu perusahaan atau produk saja.

3) Membuat sebuah website dengan tema tertentu, misalkan saja tentang buku dan budaya membaca. Disediakan banyak artikel penting di dalam web ini yang disajikan oleh pemilik web. Kemudian disajikan sejumlah ruang iklan, dimana perusahaan di bidang buku (percetakan, penerbit, toko buku) dapat meletakkan iklan mereka di sana secara gratis. Namun untuk setiap iklan yang diklik oleh pengunjung website bersangkutan dan terdapat produk yang dibeli oleh mereka, maka pemilik web berhak memperoleh komisi. Komisi ini sebagai kompensasi atas pemberian ruang iklan online dan sekaligus membantu memasarkan produk mereka ke konsumen.

4) Model Cost per Click (CPC) dan Pay Per Click (PCP) yang diterapkan baik oleh pemilik website maupun merangkap sebagai pemilik dan produsen produk, terhadap konsumen yang mau mengklik iklan yang mereka berikan secara online dan mempublikasikannya ke pengguna internet lainnya (misalnya menggunakan social media dan social network). Komisis bisa saja di tambah apabila membeli produk yang ditawarkan tersebut.

B. Proses Bisnis

Obolensky (1996) proses bisnis adalah serangkaian aktifitas-aktifitas yang saling berkaitan satu sama lain yang mengkonversikan masukan-masukan (input) bisnis menjadi suatu keluaran (output) bisnis. Proses dibagi menjadi 3 macam aktifitas pokok yaitu :

1) Aktifitas-aktifitas yang bernilai tambah (aktifitas-aktifitas yang penting yang diinginkan dan dibutuhkan pelanggan)

2) aktifitas-aktifitas hand-off (aktifitas-aktifitas yang aliran kerjanya bergerak melalui batas-batas yang terutama bersifat fungsional, departemental, ataupun organisasional)

3) aktifitas-aktifitas kendali (aktifitas yang diadakan untuk mengendalikan aktifitas hand-off melalui batas-batas yang disebutkan di atas). 
TABEL 1.

KLASIFIKASI AKTIFITAS BISNIS DALAM ORGANISASI

\begin{tabular}{|c|c|c|c|}
\hline Aspek & Peristiwa Proses Operasi & Peristiwa Proses Informasi & Peristiwa Proses Manajemen \\
\hline Komponen & $\begin{array}{c}\text { Manusia, peralatan, Organisasi, } \\
\text { Kebijakan dan Prosedur }\end{array}$ & $\begin{array}{c}\text { Peralatan, Otorisasi,Organisasi, } \\
\text { Kebijakan dan Prosedur }\end{array}$ & $\begin{array}{c}\text { Manusia, Otorisasi, Organisasi, } \\
\text { Kebijakan dan Prosedur }\end{array}$ \\
\hline Jenis Aktifitas & $\begin{array}{l}\text { Secara fisik menyediakan barang } \\
\text { dan jasa }\end{array}$ & $\begin{array}{l}\text { Mencatat/menyimpan data atas } \\
\text { peristiwa operasi, memlihara data } \\
\text { referensi yang penting, dan } \\
\text { menyajikan informasi berguna bagi } \\
\text { manajemen } \\
\text { dan pengambil keputusan lainnya }\end{array}$ & $\begin{array}{l}\text { Perencanaan, pengendalian, dan } \\
\text { evaluasi proses bisnis yang terjadi. }\end{array}$ \\
\hline Tujuan & $\begin{array}{c}\text { Menyelesaikan pekerjaan } \\
\text { organisasi dalam bentuk proses } \\
\text { bisnis }\end{array}$ & $\begin{array}{l}\text { Memfasilitasi fungsi operasi dan } \\
\text { mendukung Kebutuhan } \\
\text { pengambilan Keputusan manajemen } \\
\text { Dengan menyediakan informasi } \\
\text { yang berkualitas }\end{array}$ & $\begin{array}{l}\text { Merencanakan dan mengendalikan } \\
\text { operasi/proses bisnis organisas }\end{array}$ \\
\hline
\end{tabular}

Proses bisnis merupakan instrumen kunci untuk mengorganisir kegiatan ini dan untuk meningkatkan pemahaman tentang hubungan timbal balik proses tersebut. Sebuah proses bisnis terdiri dari serangkaian kegiatan yang dilakukan dalam koordinasi di lingkungan organisasi dan teknis. Kegiatan-kegiatan ini bersama-sama mewujudkan tujuan bisnis. Setiap proses bisnis yang telah ditetapkan oleh sebuah organisasi dapat berinteraksi dengan proses bisnis yang dilakukan oleh organisasi lain.

Desain proses bisnis merupakan penjelasan dengan detail bagaimana bagian-bagian dari sistem diimplementasikan. jika dilihat dari siklus hidup proses bisnis, maka dalam tahapan desain, sistem dalam proses bisnis diidentifikasi dan dimodelkan.

Pada tahap ini dilakukan penelitian terhadap proses bisnis dan lingkungan organisasi serta teknik dari perusahaan. Berdasarkan hal ini, proses bisnis dapat diidentifikasikan, ditinjau kembali, divalidasi, dan digambarkan dengan model proses bisnis.

\section{A. Analisis Proses Bisnis}

\section{METODE}

Ada 2 jenis e-commerce pada studi kasus, yaitu:

1) E-commerce $\mathrm{B} 2 \mathrm{C}$ yang melibatkan afiliator / supplier dengan konsumen akhir

2) E-commerce $\mathrm{B} 2 \mathrm{~B}$ yang melibatkan manufacturing supply chain

Gambar 2 menunjukkan B2C yang dilakukan secara online melibatkan supplier / afiliator dengan konsumen akhir.

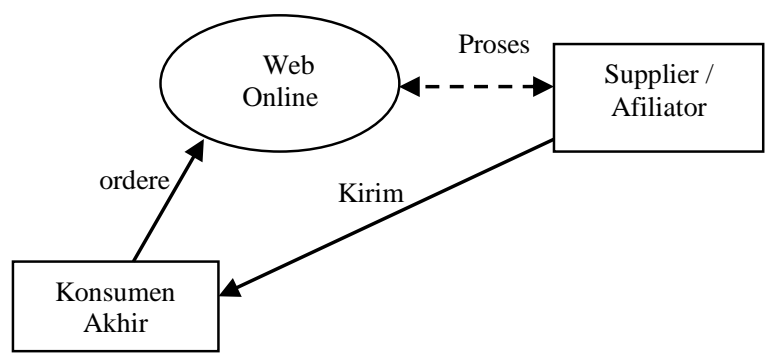

Gambar 2. Bagan e- commerce B2C antara supplier / afiliator dan Konsumen Akhir

Konsumen akhir memesan barang secara online via web online, kemudian antara web online dan Supplier memproses transaksi jual beli dan supplier mengirim barang ke konsumen akhir.

Gambar 3. menunjukkan B2B yang melibatkan Manufacturing Supply Chain. Manufacturing Supply Chain terdiri atas Supplier, Afiliator (agen) dan Konsumen Akhir. Konsumen akhir melakukan order pada web afiliator, Web afiliator mengirim data order ke web supplier. Pada kasus ini seolah olah terjadi order antara Afiliator ke Supplier berdasarkan permintaan konsumen akhir. Supplier memproses order dan mengirim barang ke konsumen akhir dan secara berkala mengirim komisi ke affiliator. Affiliator bisa memonitoring jumlah transaksi dan komisi di web afiliator baik secara online maupun berbasis android. 


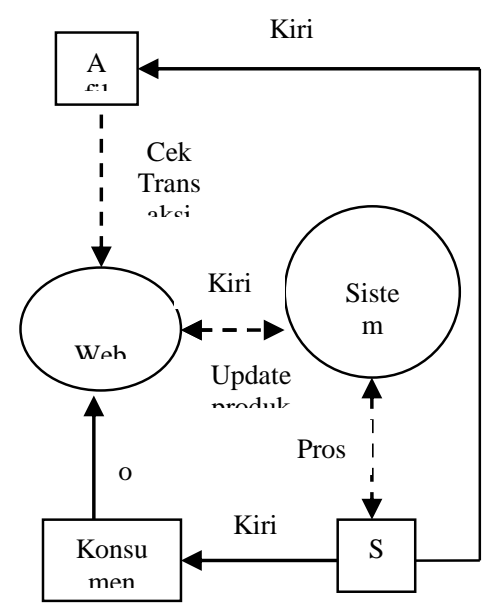

\section{B. Arsitektur Sistem}

Gambar 3. Bagan e- commerce B2B pada manufacturing supply chain

Untuk membangun sistema aplikasi B2B-B2C ini terdapat 3 subsistem yang akan dikembangkan, yaitu :

1) Sistem antar muka Supplier dengan Afiliator dengan platform android (antar muka B2B)

2) Sistem informasi penjualan berbasis online dengan server database ( sistem induk )

3) Web online antara afiliator/ Supplier dengan konsumen akhir (antar muka B2C)

Ketiga sub sistem ini terintegrasi dari beberapa proses bisnis yang melibatkan kolaborasi antara supplier, afiliator dan Konsumen akhir.

Hubungan antara sub sistem dapat dilihat pada arsitektur sistem yang ditunjukkan pada gambar 4. Dari gambar 4. terdapat 4 macam user sistem, yaitu: supplier, calon affiliator, affiliator dan pembeli. Antar user menggunakan sub sistem yang berbeda. Supplier dan affiliator dihubungkan dengan sub sistem antarmuka berbasis android. Affliiator dan pembeli dihubungkan dengan sub sistem web online. Dan calon affiliator terhubung dengan sub sistem informasi penjualan.

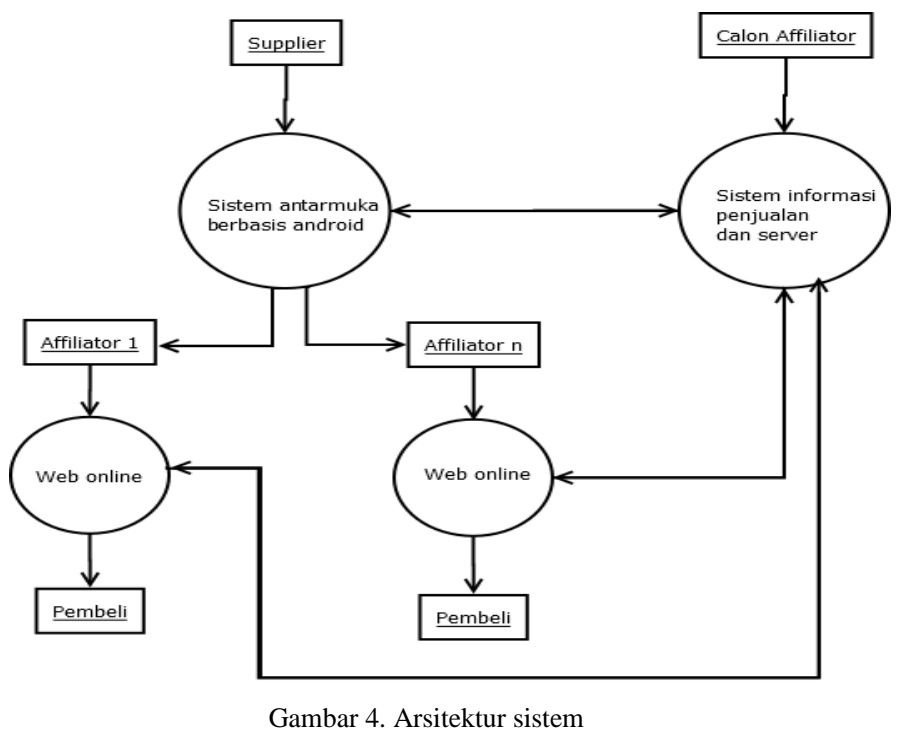

\section{Analisis Kebutuhan Pengembahan Sistem Perangkat Lunak}

Kebutuhan pengembangan sistem perangkat lunak terdiri dari: kebutuhan input, kebutuhan proses, kebutuhan output, dan analisis pengguna. Untuk mengidentifikasi kebutuhan pengembangan sistem maka dilakukan identifikasi terhadap beberapa kebutuhan input, proses dan output pada studi kasus toko pakaian / distro. Adapun kebutuhannya sebagai berikut :

Kebutuhan Input

Kebutuhan input pada sistem ini meliputi: data produk-produk barang yang akan dijual dan data para affiliator.

Kebutuhan Proses

Kebutuhan proses pada sistem ini meliputi: melihat website, pendaftaran, konfirmasi pendaftaran, mengisi alamat dan domain website, mengisi form pembelian, mengisi data dan alamat pemesanan, menerima konfirmasi 
pembelian, konfirmasi pembayaran, mengubah status pembelian, mengirim aplikasi dan tutorial, login, mengisi atau update produk, update data diri (affiliator), melihat komisi.

Kebutuhan Output

Adapun keluaran (output) yang dihasilkan adalah berupa komisi yang didapat oleh affiliator dari setiap transaksi pemesanan oleh konsumen (pembeli).

D. Diagram Use Case

Diagram use case merupakan gambaran perilaku dari semua aktor sistem. Terdapat empat aktor yang teridentifikasi, yaitu: calon affiliator, pembeli, /supplier dan afiliator. Kemudian terdapat beberapa use case, antara lain: melihat website, pendaftaran, konfirmasi pendaftaran, mengisi alamat dan domain website, mengisi form pembelian, mengisi data dan alamat pemesanan, menerima konfirmasi pembelian, konfirmasi pembayaran, mengubah status pembelian, mengirim aplikasi dan tutorial, login, mengisi atau update produk, update data diri (affiliator), melihat komisi. Diagram use case pada sistem ditunjukkan pada gambar 5. Pada Gambar 5. terlihat 17 use case context dan 6 use case requirement. Perilaku perilaku actor terhadap sistem digambarkan sebagai berikut:

1) Calon afiliator, beberapa aktifitas yang dapat dilakukan terhadap sistem adalah melihat web supplier, melakukan pendaftaran sebagai afiliator, mengisi alamat domain website yang diinginkan, dan menerima konfirmasi dari sistem

2) Pembeli, aktifitas yang dapat dilakukan terhadap sistem adalah melihat website, mengisi form pembelian, mengisi form data dan alamat pemesanan, menerima konfirmasi pembelian, dan mengkonfirmasi pembayaran

3) Supplier, beberapa aktifitas yang dapat dilakukan terhadap sistem adalah melakukan login, mengubah status pembelian, mengisi / update produk, mengirim aplikasi dan tutorial, menghapus data afiliator dan update data afiliator

4) Afiliator, memiliki aktifits aktifitas terhadap sistem yaitu: melakukan login, melihat komisi dan melihat website

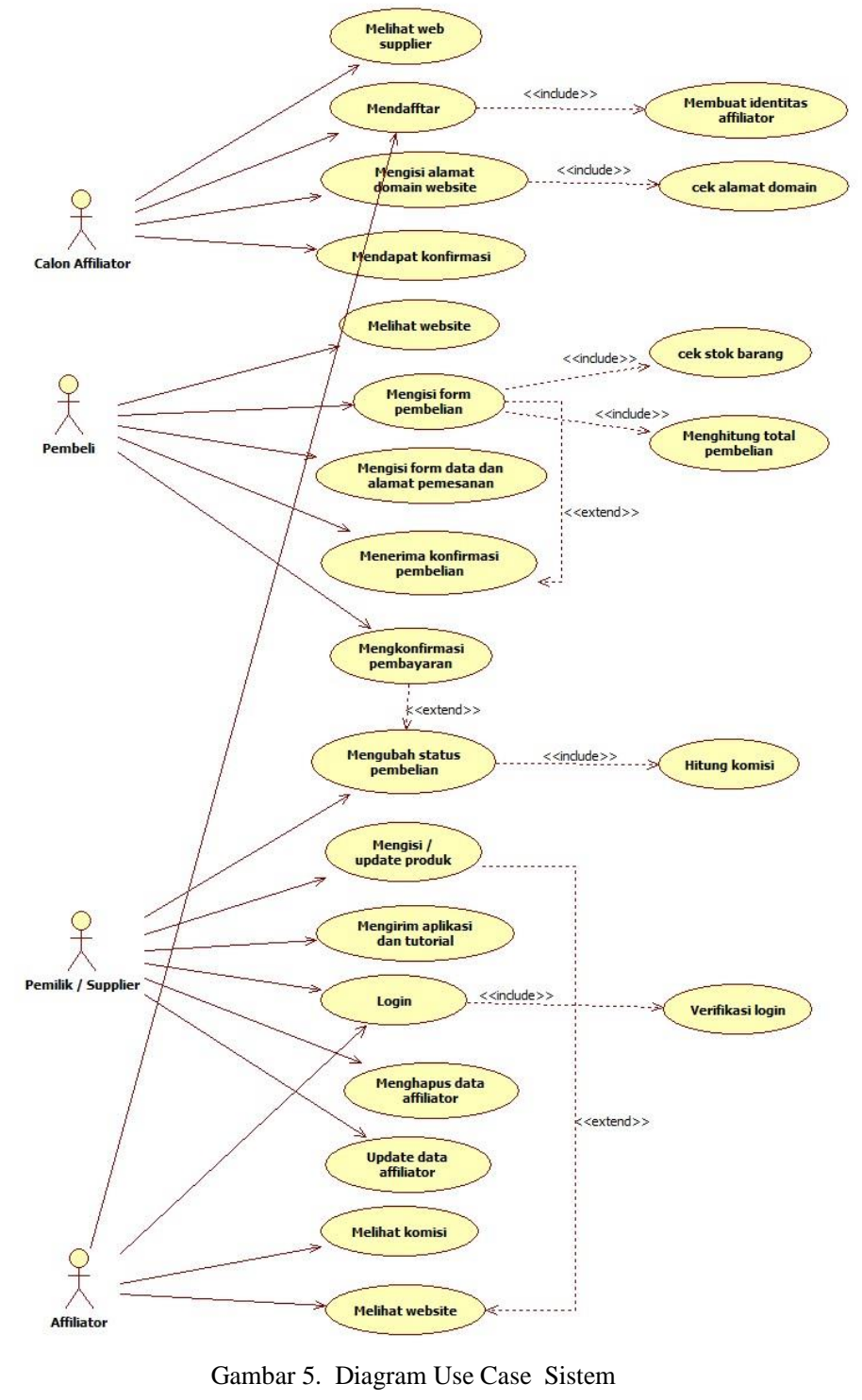




\section{E. Diagram Kelas}

Pada diagram class ini terdapat beberapa kelas serta paket-paket yang ada dalam sistem yang akan dibangun. Diagram Class pada sistem ditunjukkan pada gambar 6.

\section{F. Relasi Tabel}

Relasi tabel menunjukkan hubungan atau interaksi antara beberapa tabel yang dibutuhkan dalam membangun sistem. Terdapat 5 tabel, yaitu: tabel barang, tabel pembayaran tabel pembelian, tabel affiliator dan tabel user. Relasi tabel pada sistem ditunjukkan pada gambar 7.
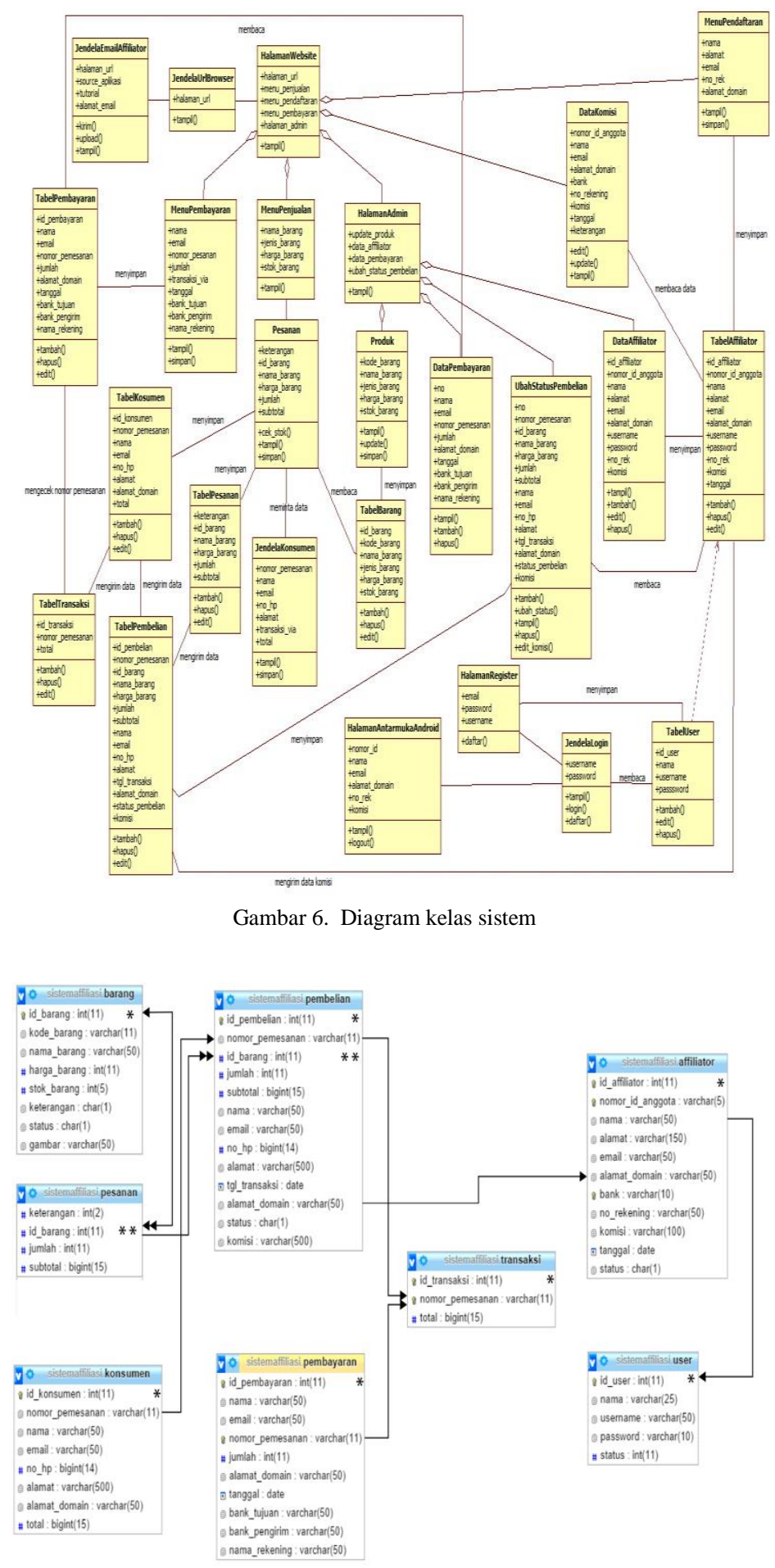

Gambar 7. Relasi Tabel 


\section{HASIL}

Sistem Informasi Penjualan berbasis web adalah sistem di sisi penyedia barang / Supplier yang merupakan web utama yang memiliki menu Home, Profil, Konfirmasi Pembayaran, Pendaftaran Afiliator, Kontak, Keranjang, Pencarian dan Kategori barang seperti ditunjukkan Gambar 8.

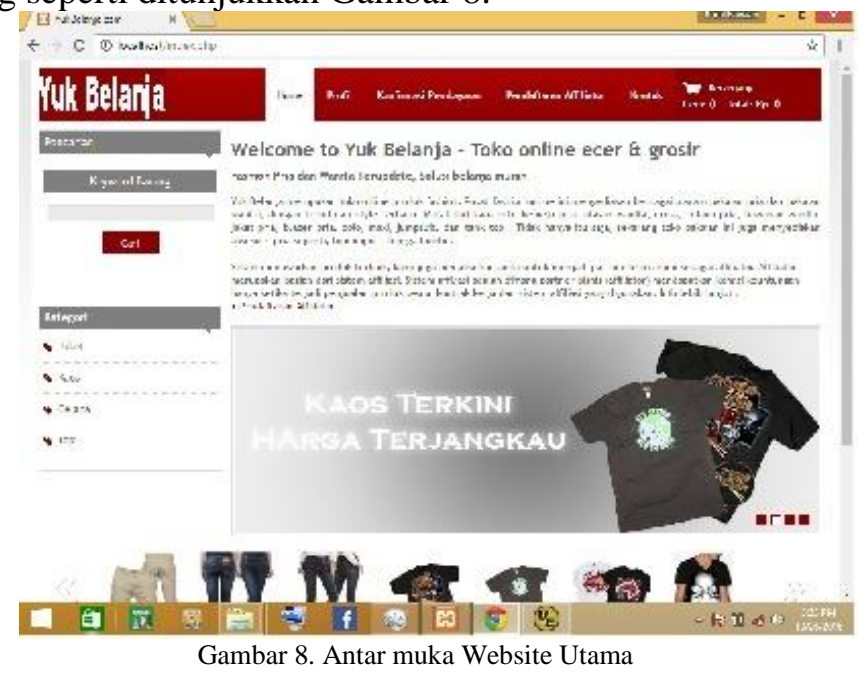

Calon afiliator dapat melakukan pendaftaran afiliator dengan memilih menu Pendaftaran Afiliator sehingga muncul antar muka Buat Akun Afiliator seperti ditunjukkan gambar 9. kemudian mengisi data diri meliputi nama, alamat, email, alamat domain, bank, no rekening sebelum melakukan submit.

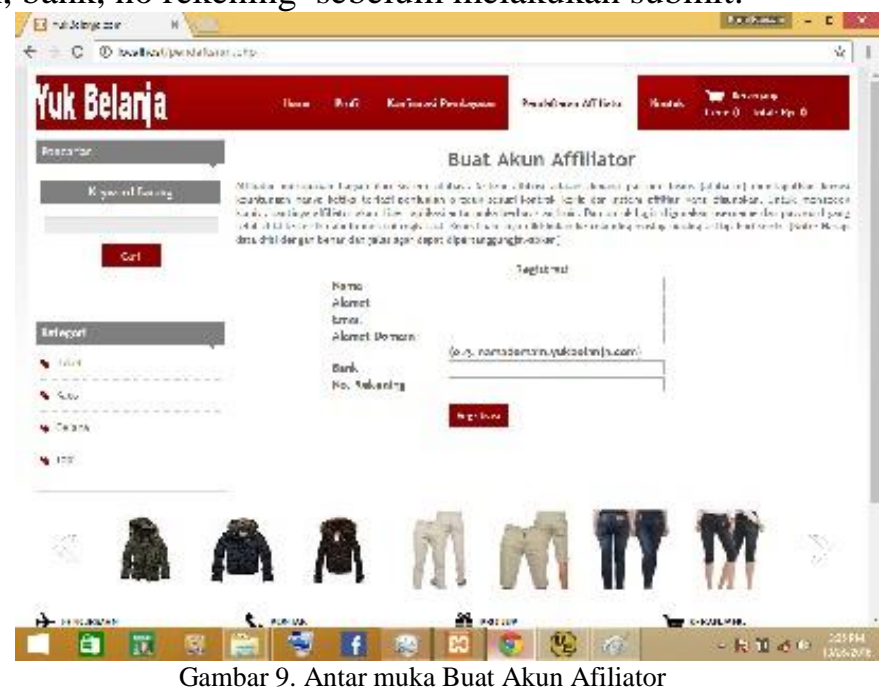

Alamat domain yang diisi afiliator akan menjadi subdomain pada Web Utama dan disediakan fasilitas validasi subdomain. No rekening afiliator yang diisi digunakan untuk mentransfer komisi afiliator bukan untuk transfer transaksi pembelian barang. Transfer transaksi pembelian melalui rekening penyedia barang yang tercantum juga pada web afiliator. Calon Afiliator yang telah melakukan pendaftaran akan dikirim staterkit berupa aplikasi antarmuka berbasis android untuk mengecek komisi dan aplikasi web afiliator melalui email afiliator. Jika pembeli melakukan transaksi pembelian lewat web afiliator maka data pembelian langsung terkirim ke Web Utama untuk diproses, setelah pembeli melakukan konfirmasi pembayaran lewat web afiliator yang juga langsung terkirim datanya ke web utama maka penyedia barang memproses pengiriman barang. Pada proses pengiriman barang alamat pengirim tetap menggunakan afilitor sehingga konsumen hanya mengenal afiliator, ini untuk melindungi pelanggan pelanggan afiliator. Untuk mengecek komisi afiliator dan komunikasi antara afiliator dengan penyedia barang menggunakan aplikasi antarmuka berbasis android. Setiap Web Utama memperbaharui katalognya maka otomatis web afiliator juga akan terbaharui katalognya. 
Jurnal Informatika dan Komputer (JIKO) - Vol. 2, No. 1, Februari 2017

\section{PEMBAHASAN}

Penelitian ini telah diuji dengan menggunakan black box testing dengan hasil semua modul berjalan dengan baik, lihat tabel II.

TABEL II.LIST PENGUJIAN MENGGUNAKAN BLACK BOX TESTING

\begin{tabular}{ccc}
\hline \hline Input & Output & Hasil \\
\hline index.php & Halaman utama web & Berjalan Baik \\
\hline admin.php & Halaman login admin & Berjalan Baik \\
\hline dataaffiliator.php & Halaman data affiliator & Berjalan Baik \\
\hline datapembelian.php & Halaman data pembelian & Berjalan Baik \\
\hline datapembayaran.php & Halaman data pembayaran & Berjalan Baik \\
\hline ubahstatus.php & Halaman ubah status & Berjalan Baik \\
\hline datakomisi.php & Halaman data komisi & Berjalan Baik \\
\hline halaman_login.xml & Halaman login android & Berjalan Baik \\
\hline \hline halaman_utama.xml & Halaman utama android & Berjalan Baik \\
\hline \hline halaman_regis.xml & Halaman regis android & Berjalan Baik \\
\hline \hline
\end{tabular}

V. SIMPULAN DAN SARAN

Penelitian ini menghasilkan suatu sistem E-Commerce B2B-B2C berbasis online untuk antar muka konsumen akhir bertransaksi dan berbasis mobile untuk antar muka antara affiliator dan supplier / pemilik barang. Dari Hasil Pengujian sistem dapat mengelola data affiliator, data barang, transaksi penjualan dan komisi untuk affiliator, produk-produk baru terupdate secara real time., data para affiliator teridentifikasi dengan baik.

Penelitian ini fokusnya adalah mengeksplorasi implementasi sistem affiliator dalam mendukung proses bisnis B2B-B2C, sehingga jika ingin di operasikan di dunia e-commerce masih memiliki beberapa kekurangan dalam optimalisasi layanan. Untuk Optimalisasi layanan aplikasi yang lebih baik pada hasil penelitian ini, beberapa saran pengembangan dapat dilakukan yaitu

1) Pengiriman aplikasi dan tutorial bagi affiliator baru hendaknya dapat dilakukan oleh sistem secara otomatis, tanpa email manual dari operator.

2) Proses perhitungan komisi bisa dilakukan secara otomatis tanpa melibatkan admin.

\section{REFERENSI}

[1] Jannatun. N, "Rancang Bangun Sistem Afiliasi Pada Zifara Mebel Berbasis Web,” http://eprints.dinus.ac.id/id/eprint/13344, 2014, diakses pada tgl 4 September 2015 pukul 15.51. WIB

[2] Nugroho, A., "E-commerce Memahami Perdagangan Modern di Dunia Maya", Penerbit Informatika, Bandung, 2006

[3] Obolensky, N., " Practical Business Re-engineering,” Elex Media Komputindo, 1996

[4] Pratama, I.P.A.E, “ E-commerce, E- Business dan Mobile Commerce Berbasiskan Open Source,” Penrbit Informatika, Bandung, 2015

[5] Safitri, A . dan Sujito, "Website Paramita Member Club Dengan Menerapkan Model Affiliate Marketing, " Jurnal tehnologi Informasi Pradnya Paramita, ISSN 2086-29889, Vol.2 No.2, 2013

[6] Sufendi, dkk, "Rancang Bangun E-commerce Penjualan dan Pemesanan Pakaian Batik Pada Julier Batik," http://eprints.dinus.ac.id/id/eprint/4764, 2013, diakses pada tanggal 3 September 2015 pukul 15.45 WIB

[7] Wong, dkk, "” Analisis dan Perancangan E-commerce Handphone dan Komputer Berbasis Website," Journal on Networking and Security, Vol 2 No 1 - Juli 2013, Universitas Surakarta, Solo, 2013

[8] Agustin Setyo Wardani, "Tahum ini diprediksi Pasar Belanja Online Naik dua kali Lipat", http://wartakota.tribunnews.com/2015/01/22/tahun-ini-pasar-belanja-online-diprediksi-naik-dua-kali-lipat, 2015, diakses pada tgl 4 September 2015 Pukul 16.30. WIB. 